\title{
The Role of Marketing Tools in the Improvement of Consumers Financial Literacy
}

\author{
Sergejs Paramonovs ${ }^{1}$, Ksenija Ijevleva ${ }^{1},{ }^{1}$ University of Latvia
}

\begin{abstract}
The aim of the paper is to explore the contribution of different types of marketing communication in consumer financial literacy formation from a three component perspective. As a method a survey among the target audience of home loans was used. The authors have focused on consumer financial knowledge, financial behaviour and financial attitude that constitute financial literacy in home loan market. As a result of empirical analysis the authors have found that the biggest contribution to formation of consumers financial literacy (within all three components) have educational web sites of government authorities, official web sites of banks, consultations with bank specialists, school curriculum subjects and opinions of friends, relatives and acquaintances.
\end{abstract}

Keywords - Social marketing, consumer financial literacy, home loan market.

\section{INTRODUCTION}

Over the last two decades, the home loan market of Latvia has experienced a sharp development followed by a decline caused by a variety of factors including the lack of financial literacy from consumers. Though, besides the poor consumer awareness, one of the principal reasons for market fluctuations was the ill-considered marketing activities implemented by commercial banks and state authorities. For instance, upon introducing financial products to the market via marketing elements, one often emphasizes the advantages of the product and such marketing campaigns do not inform potential consumers in a broader manner.

The term of financial literacy is interpreted by various researchers in different ways, thus it is generally reflected in the varying meanings used in the scientific theoretical literature and found in the official reports of various governmental authorities. Financial literacy is rather a comprehensive term, which is understood as both major understanding of economics and finance as well as the fact that economic circumstances and conditions affect households' welfare and decisions. Scholar Worthington (2006) prefers a more narrow explanation of the term, and focuses on consumer knowledge about savings, budgeting, insurance and investments. While the American Institute of Certified Public Accountants (AICPA) has explained the term in a comprehensive manner, i.e. as individuals' ability to efficiently assess and manage one's finance in order to make well-considered decisions for the attainment of one's life aims and achievement of financial welfare. The Organisation for Economic Co-operation and Development (OECD) defines the term of financial literacy as follows: "combination of understanding, knowledge, skills, attitude and behaviour that is required in order to make correct financial decisions subsequently attaining individual financial welfare" (Atkinson, \& Messy, 2012). Klinsky and Chroma (2009) have structured the definition of financial literacy simply from the standpoint of economic knowledge - financial literacy as an administration of private and household welfare includes three economic components: knowledge of money, budget and prices. According to the view of other authors (SEDI, 2006), financial literacy does not only contain knowledge of money, prices and budget, it is a three-dimensional phenomenon which includes: financial knowledge and understanding, financial competency and skills as well as financial responsibility.

The authors have found out from the scientific works of other researchers that the scholars of financial literacy do not use a uniform definition. Therefore the authors have offered to complement the definition in a manner that is more appropriate for the problem at hand - financial literacy is a set of financial knowledge, financial behaviour and financial attitude that is necessary to make considerate financial decisions for the achievement of one's life goals in order to achieve one's individual welfare (Fig. 1).

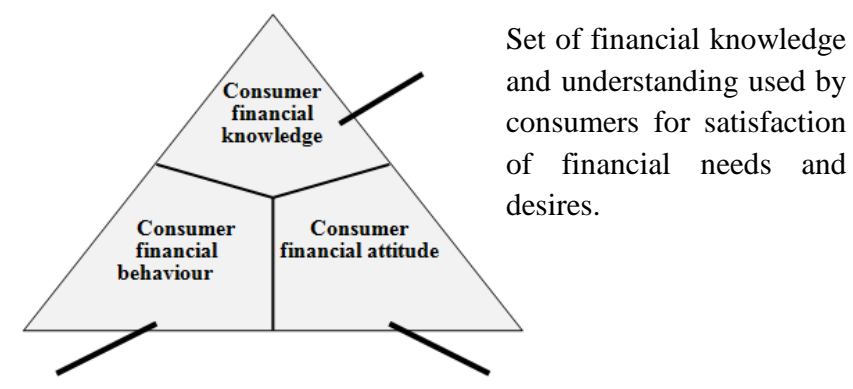

Consumers' specific action in the financial market (for Relatively persistent evaluating reaction oriented towards specific financial objects (for example, financial institutions) and process that affect related decisions offer).

Fig. 1. Components of consumer financial literacy on the basis of OECD survey

The authors emphasize that with the use of marketing tools, the said three components must be developed simultaneously since these components are integral to each other and relate with each other. Therefore the aim of the paper is to determine the contribution of different types of marketing communication to consumer financial literacy formation from the said component perspective. The consumer financial knowledge is considered to be the most general component hence it requires a superior degree of attention from the researchers. In order to have a more effective financial education process, one must pay attention to all components of 
consumer financial literacy due to the fact that all educational elements must involve all relevant factors. Thus the facilitation of consumer financial knowledge, behaviour and attitude lead to a higher level of consumer financial literacy.

In order to investigate the contribution of different types of marketing communication to the formation of consumers' financial literacy, the authors chose such quantitative method as survey and further analysis of it. According to OECD/INFE organization's statement, the estimation of levels of consumer financial literacy is a key factor of sustainable national strategies and tactics for financial education (web-site of OECD), allowing policy makers to determine the drawbacks and gaps and create appropriate responses (web-site of APEC). Resembling patterns are defined among countries, local national authorities can contribute together to identify common approaches for improving consumer financial literacy within their related populations.

Many researchers (Meiera, \& Sprenger, 2012) as well state, that consumers with poor level of financial literacy have difficulties to choose among products and services, which suite their needs most (Altman, 2012). It is difficult to evaluate the given advice, and they may become victims of unfair trade practices (Van Rooij, Lusardi, \& Alessie Rob, 2011). There is general misunderstanding observed about financial products, and especially, if they are complicated and comprehensive (Lo Prete, 2013). As a result, there are two possible outcomes - people avoid using financial services (financial backwardness) or they get involved, but often make a choice of a product, which does not suite their needs best. The latter is due to a difficulty they have to compare a full range of product available on the market.

In line with the World Bank data, the home loan market in Latvia over the past ten years has proven a sharp growth followed by the fall caused by a variety of reasons including the lack of financial awareness on the part of the consumers. However, besides the low consumer literacy, one of the main causes for drastic market fluctuations were also the illconsidered marketing activities implemented by state authorities and commercial banks (Morris, \& Clarkson, 2009). For instance, upon promotion of financial products to the market via marketing elements, one often highlights the benefits of the product and, to our regret, such marketing campaigns do not encourage comprehensive information of consumers (OECD, 2009).

The following two tendencies determine issues in the area of consumer financial literacy. First of all, consumers are faced with incessantly growing complexity and availability of the financial services and products, while state authorities and commercial banks do not respond to these facts during implementation of commercial and social marketing activities (Cole, Sampson, \& Zia, 2011). Secondly, financial consulting of consumers lags behind the level of complexity of contemporary financial products (Meier, \& Sprenger, 2012). In our modern society, consumers are far from acting in a financially rational manner due to the strong pressure caused by the flow of information. At the same time, the financial markets are open and lending resources are available, thus consumers are using them widely and as a result exceed the capabilities of budget or contrariwise choose to take an observatory stance and apart themselves from the development in the financial markets and are not adapting to financial information, not following up with financial market activities and finally - rendering themselves incompetent in understanding the situation of financial markets (Collins, 2013).

\section{SOCIAL MARKETING ELEMENTS IN THE IMPROVEMENT OF CONSUMERS FINANCIAL LITERACY}

The communication between companies, national authorities and consumers in the area of finance has changed over the course of the last decade. It has evolved from simple information providing to society a more composite approach, which is based on the combination of techniques, the set of which marketing experts refer to as "social marketing". The alter is focused towards a more comprehensive dissemination of information from commercial banks and national authorities by paying attention to population's desires and needs instead of barely providing a "top-to-bottom" information. Social marketing as a discipline has arisen in 1970 when Philip Kotler and Gerald Zaltman determined that the same principles of marketing that are used in the promotion of products to consumers, may be applied in order to "sell" ideas, behaviour and attitudes. The researcher Andersen (2002) explained social marketing as an "area of marketing that differs from "traditional marketing" only in the set of goals". Therefore, social marketing is aimed at affecting consumers' social behaviour for the benefit of the target audience at large instead of a business.

The development of consumer financial literacy is not achievable without formation of financial attitude and financial behaviour within financial knowledge, so this precondition is proposed to be realized via marketing communication.

Marketing communication entails dissemination of information about companies, prices, products, product placement, sale and other marketing events in order to impact consumer action (Praude, \& Šalkovska, 2005-2006. p. 17). In the context of the paper, marketing communication is education of consumers in order to impact the financial literacy thereof. According to the opinion of Kotler (2009, p. 478), dissemination of information is done via the following types of marketing communication:

- interactive marketing;

- advertising;

- direct marketing;

- sales promotion;

- personal selling;

- events and experiences;

- PR.

It is vital to employ such aspects in marketing communication that conform to the satisfaction of communicative needs of the market members. Similar to the marketing mix $4 \mathrm{P}$, the types of marketing communication may be interpreted in social marketing (Robertson, \& Davidson, 
2013). These may be the following in the context of improving financial literacy:

- interactive marketing - official websites of commercial banks and state authorities, educational websites created by commercial banks and national institutions;

- home loan advertising (for instance, online or on television) and social advertising, for example, a reminding ad of "Borrow responsibly!";

- direct marketing - school and university curriculum subjects. In the view of the authors, population's education in schools and universities may not only be counted as direct social marketing because upon conducting specific planning and integration of learning material, it is an approach that allows obtaining and educating a maximum number of new consumers;

- direct sales - consultations with bank and state authorities specialists, consultations with specialists not directly related to lending (for instance, real estate brokers), as well as opinions provided by relatives, friends and acquaintances;

- event and experience marketing - Financial Education Week held by FCMC, topical exhibitions (for example, real estate property exhibitions);

- PR - information rendered by media, for example, articles in newspapers, TV shows and articles in news websites.

Therefore the expression of social marketing types in financial literacy is possible within customer education only. It is in line with the definition of Strategy of Latvian Population's Financial Literacy: "Financial education is acquisition of knowledge and skills about finance and the interrelation thereof" (2014).

\section{METHODOLOGY}

On the basis of analysis of empirical studies, interviews with experts and the research of academic literature the authors ascertained that in Latvia hitherto there have been no marketing studies of financial literacy on the home loan market. The results of the research carried out by the authors and other scholars are not enough to determine the financial literacy level of home loan target audience, its potential and possible behaviour in various cases. Thus the authors by means of two surveys have analysed the consumers' financial literacy level and the role of social marketing communication tools in the improvement of consumers' financial literacy level.

In order to ensure a representative sample for survey in quantitative research of home loan target audience, the authors have determined the demographic profile of home loan target audience by including a relevant question in the questionnaire of seven experts survey (Ijevleva, 2014). According to the experts' survey results, the majority of home loan target audience consists of:

- $\operatorname{men}(57 \%)$;

- residents of Riga (25\%);

- residents at 25-34 years of age (43\%);

- residents with higher education $(61 \%)$;

- employed (98\%).
The resulting profile should be considered to be a qualitative description of general population. The comparison of the received sample with general population, including the demographic profile, is depicted in Table I, the data of which prove that the given sample is representative of general population.

TABLE I

COMPARISON OF SAMPLE RECEIVED FROM THE FINANCIAL LITERACY MEasuring Survey with General Population, August - October 2013

\begin{tabular}{|c|c|c|}
\hline \multirow[t]{2}{*}{ Profile } & $\begin{array}{l}\text { Proportion of } \\
\text { respondents in the } \\
\text { sample }\end{array}$ & $\begin{array}{l}\text { Profile home loan } \\
\text { market target } \\
\text { audience (in opinion of } \\
\text { experts) }\end{array}$ \\
\hline & $100 \%$ & $100 \%$ \\
\hline \multicolumn{3}{|c|}{ Gender } \\
\hline Female & $49.30 \%$ & $43 \%$ \\
\hline Male & $50.70 \%$ & $57 \%$ \\
\hline \multicolumn{3}{|c|}{ Residency } \\
\hline Riga & $26.30 \%$ & $25 \%$ \\
\hline Greater Riga & $17.80 \%$ & $21 \%$ \\
\hline Vidzeme & $12.40 \%$ & $8 \%$ \\
\hline Kurzeme & $13.50 \%$ & $16 \%$ \\
\hline Zemgale & $21.70 \%$ & $23 \%$ \\
\hline Latgale & $8.30 \%$ & $7 \%$ \\
\hline \multicolumn{3}{|c|}{ Age } \\
\hline $18-24$ & $7.30 \%$ & $9 \%$ \\
\hline $25-34$ & $45.50 \%$ & $43 \%$ \\
\hline $35-44$ & $21.30 \%$ & $19 \%$ \\
\hline $45-54$ & $16.10 \%$ & $18 \%$ \\
\hline $55-80$ & $9.80 \%$ & $11 \%$ \\
\hline \multicolumn{3}{|c|}{ Employment } \\
\hline Employed persons & $95.80 \%$ & $98 \%$ \\
\hline $\begin{array}{l}\text { Unemployed } \\
\text { persons }\end{array}$ & $4.20 \%$ & $2 \%$ \\
\hline \multicolumn{3}{|c|}{ Education } \\
\hline Basic education & $1.30 \%$ & $2 \%$ \\
\hline $\begin{array}{l}\text { Secondary } \\
\text { education }\end{array}$ & $9.40 \%$ & $11 \%$ \\
\hline $\begin{array}{l}\text { Not finished } \\
\text { higher education }\end{array}$ & $27.80 \%$ & $26 \%$ \\
\hline Higher education & $61.50 \%$ & $61 \%$ \\
\hline
\end{tabular}

Source: Designed by the authors according to results of survey, 2013, $n=431$

The authors conclude that the home loan is a complicated product that requires high consumers' involvement and is not easily accessible to any Latvian resident therefore the home loan target audience consists of educated, employed and mature residents of Latvia.

The authors have elaborated the survey among the home loan market target audience to evaluate the contribution of each type of marketing communication to the formation of consumers' financial literacy. Relying on the data of the home loan target audience demographic profile provided by seven experts, the authors divided the survey sample by age, gender, 
education, residency, as well as income and status. The sample consisted of 431 respondents. The survey was conducted in the period of time from August to October 2013 (see Table II).

\section{TABLE II}

TECHNICAL INFORMATION RECEIVED FROM THE SURVEY ON FINANCIAL LITERACY MEASURING, AUGUST - OCTOBER 2013

\begin{tabular}{|l|c|}
\hline General population & Home loan market target audience in Latvia \\
\hline Sample planned & 450 respondents \\
\hline Sample received & 483 respondents \\
\hline Sample valid & 431 respondents \\
\hline Sample method & Stratified random sampling \\
\hline Period survey conducted & 5-26 August 2013 \\
\hline
\end{tabular}

Source: Designed by the authors according to results of survey, 2013, $n=431$

In order to provide the representative sample, the authors took into account the recommendations of researchers Greenlow (2009) and Schonlau (2003) - respondents were surveyed by phone and e-mail survey methods. With the opportunity to track data and results online, if necessary it is possible to manage and react interactively, because it allows directing the survey at more representative sample (Dolnicar, Laesser, \& Matus, 2009).

According to the statement of Organisation for Economic Co-operation and Development (OECD) the society may be considered as financially literate, if at least $70 \%$ of residents have sufficient level of financial literacy. In the framework of the research theme the authors also have admitted that home loan target audience can be assumed as financially literate, if at least $70 \%$ of customers have efficient or high level of financial literacy.

\section{EMPIRICAL ANALYSIS}

To measure the financial level 23 questions were developed, therefore, to consider housing loan audience as financially literate the arithmetical mean of correct answers must be above 17. The process of financial literacy scores calculation was implemented by counting the number of correct answers given by each respondent and computing an arithmetical mean of the scores of all respondents. Therefore the authors have obtained the data that indicate the lack of financial literacy among home loan target audience, because the arithmetical mean of correct answers is equal to 10.9 that is below the minimum, moreover, most often the number of correct answers is 10 . The median is equal to 11 , meaning that 11 is the central value of correct answers grouped in ascending order, thus the author concludes that half of the respondents have correctly answered to $50 \%$ of questions.

The survey for the assessment of financial literacy among the home loan market target audience focuses on consumer financial knowledge, financial attitude, financial behaviour, that is, components that make up the financial literacy on home loan market.

To investigate the contribution of marketing communications, the authors have included the relevant question in the questionnaire "Evaluate how much the following marketing activities contribute to your financial literacy level. Please mark your answer on a ten-point scale, where 1 - activity does not contribute to your financial literacy at all; 10 - activity extremely contributes to your financial literacy level". Taking into account that the effectiveness of marketing communications can be drawn from the obtained results, that is, consumers' financial literacy level, the authors in Table III have analysed the estimates provided by those respondents, whose level is sufficient and high (proportion of correct answers is more than $50 \%$ within the question for the assessment of financial literacy level). Financial literacy scores were not transformed into the data in Table II, but they were used to determine those respondents who have high financial literacy level, in order to include their assessment of marketing activities that are performed in Table III. In such a way marketing activities were linked with the scores of financial literacy.

Marketing activities were divided into six types of marketing communications. Then the arithmetical means were calculated to determine which of the activities have the biggest contribution to the formation of financial literacy from the perspective of financial knowledge, behaviour and attitude. As a result of data processing (Table II) the authors have found out that the major contribution to consumers financial literacy formation (in the context of all three components) ensure such social marketing activities as official websites of commercial banks $(x=8.52)$, educational websites of state authorities $(x=6.71)$, school curriculum subjects $(x=7.83)$, consultations with bank specialists $(x=7.88)$ and opinions of relatives, friends and acquaintances $(x=7.15)$.

On the basis of financial literacy measuring survey within home loan market target audience the authors conclude: the level of financial literacy among the consumers of home loans is insufficient, thus there is a necessity to form marketing activities provided by government authorities and commercial banks in order to raise the literacy level.

Taking into consideration that there is no official national project, system and program to increase consumers' financial literacy via social marketing on the home loan market in Latvia, the authors suggest to set the aim of financial education, provide its stages and design suitable tools of social marketing communications for each stage. In order to define the aims of participants involved in consumer education and reflect objectives and marketing tools needed for financial literacy rising, the authors have developed a unified social marketing model. 
TABLE III

CONTRIBUTION OF SOCIAL MARKETING COMMUNiCATIONS ACTIVITIES TO THE CONSUMERS' FinANCIAL LITERACY BY THREE FinANCIAL LITERACY COMPONENTS

\begin{tabular}{|c|c|c|c|c|c|c|c|}
\hline \multirow{6}{*}{$\begin{array}{l}\text { Types of Social } \\
\text { Marketing } \\
\text { Communication }\end{array}$} & \multirow{3}{*}{ Activities } & \multicolumn{6}{|c|}{ Components of Financial Literacy } \\
\hline & & \multicolumn{2}{|c|}{ Knowledge } & \multicolumn{2}{|c|}{ Behaviour } & \multicolumn{2}{|c|}{ Attitudes } \\
\hline & & $\bar{x}$ & $\mathbf{s} \bar{x}$ & $\bar{x}$ & $\bar{s} \bar{x}$ & $\bar{x}$ & $\bar{s} \bar{x}$ \\
\hline & Educational web sites of banks & 5.13 & 0.10 & 4.81 & 0.10 & 4.96 & 0.07 \\
\hline & $\begin{array}{l}\text { Official web sites of } \\
\text { government authorities }\end{array}$ & 4.32 & 0.11 & 4.58 & 0.11 & 5.04 & 0.08 \\
\hline & $\begin{array}{l}\text { Educational web sites of } \\
\text { government authorities }\end{array}$ & 6.71 & 0.08 & 7.25 & 0.11 & 7.08 & 0.08 \\
\hline \multirow{2}{*}{ Advertising } & Advertisement of home loans & 2.46 & 0.11 & 2.17 & 0.08 & 2.97 & 0.08 \\
\hline & Social advertising & 1.54 & 0.08 & 1.91 & 0.09 & 2.25 & 0.09 \\
\hline \multirow{3}{*}{$\begin{array}{c}\text { Direct } \\
\text { marketing }\end{array}$} & School curriculum subjects & 7.83 & 0.12 & 8.05 & 0.08 & 8.16 & 0.10 \\
\hline & $\begin{array}{l}\text { Curriculum subjects of higher } \\
\text { educational establishments }\end{array}$ & 6.12 & 0.08 & 5.43 & 0.08 & 4.03 & 0.09 \\
\hline & $\begin{array}{l}\text { Courses related to economics } \\
\text { and finance }\end{array}$ & 1.06 & 0.11 & 0.96 & 0.07 & 0.99 & 0.10 \\
\hline \multirow{4}{*}{ Direct selling } & $\begin{array}{l}\text { Consultations with bank } \\
\text { specialists }\end{array}$ & 7.88 & 0.06 & 8.21 & 0.08 & 8.05 & 0.07 \\
\hline & $\begin{array}{l}\text { Consultations with specialists } \\
\text { of government authorities }\end{array}$ & 5.16 & 0.08 & 4.34 & 0.08 & 4.03 & 0.08 \\
\hline & $\begin{array}{l}\text { Consultations with semi-related } \\
\text { specialists }\end{array}$ & 4.01 & 0.06 & 2.06 & 0.07 & 2.87 & 0.07 \\
\hline & $\begin{array}{l}\text { Opinions of relatives, friends, } \\
\text { acquaintances }\end{array}$ & 7.15 & 0.07 & 8.73 & 0.06 & 8.75 & 0.07 \\
\hline \multirow{2}{*}{$\begin{array}{l}\text { Events and } \\
\text { experiences of } \\
\text { marketing }\end{array}$} & Financial Education Week & 1.27 & 0.12 & 0.92 & 0.09 & 0.96 & 0.07 \\
\hline & Thematic exhibitions & 3.22 & 0.09 & 2.26 & 0.12 & 2.01 & 0.07 \\
\hline Public Relations & Media & 5.76 & 0.11 & 7.31 & 0.10 & 8.03 & 0.08 \\
\hline
\end{tabular}

Source: Designed by the authors according to results of survey, 2013, $n=431$

Thus the authors propose to engage all home loan market participants in a unified social marketing model - state, commercial banks and consumers, each of them carrying out their objectives with various social marketing elements. The authors also suggest common aims and tasks to be stated by authorities and commercial banks. Considering that financial literacy by definition is a set of financial knowledge, behaviour and attitude, the authors propose to affect all components simultaneously.

According to the unified social marketing model participants have to provide general background for consumers' education, that is, consumers will be influenced from two directions, while the impact will be expressed via marketing tools. In order to show the operating principle of unified social marketing model the authors have illustrated the one in Fig. 2.

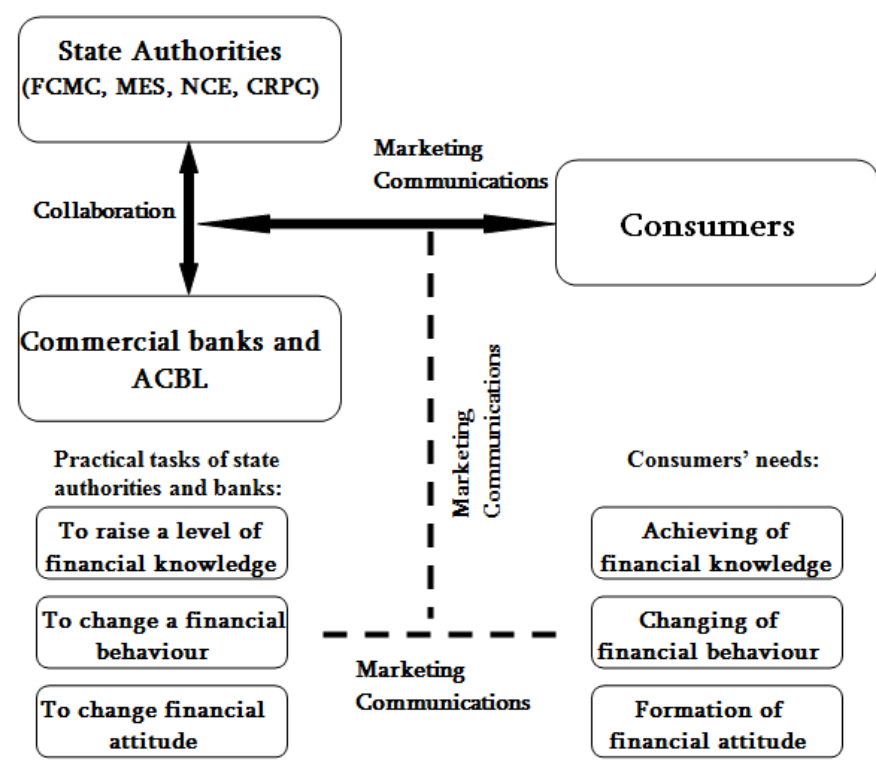

Fig. 2. The operating principle of the unified social marketing model in financial literacy level rising within home loan market (designed by authors). 
To attain higher level of consumers' financial literacy, it is necessary to modify consumer behaviour towards their consciousness. This means that consumers themselves must be interested to become more competent. Therefore, the authors propose that commercial banks and state authorities have the following common goal - to increase consumers' consciousness in relation to private finance, simultaneously improving consumers' financial literacy within home loan field. By attaining this goal, the consumers' knowledge will not disappear with time, but on the contrary, will be applied and multiplied, as individuals will be incited to acquire new knowledge, information and skills, thus, continuing the formation of financial literacy, the developers of educational programs will spend less resources for periodical reminding about the necessity and opportunities of education.

\section{CONCLUSION}

Educational programs have to be promoted via effective types of marketing communications, with focus on reflecting financial knowledge, behaviour and attitudes. As a result of empirical analysis the authors have found that the greatest contribution to the formation of consumers' financial literacy (within all three components) was made by educational web sites of government authorities, official web sites of banks, consultations with bank specialists, school curriculum subjects and opinions of friends, relatives and acquaintances.

Financial education and awareness may help consumers to develop an independent, based on their primarily personal opinion approach to either presently available products or to the products under consideration for buying in future. Education programs should primarily concentrate on aspects of consumers' needs and their life management. The state authorities have to follow, support and be actively involved in financial literacy improvement activities of enterprises and organizations.

\section{REFERENCES}

Altman, M. (2012). Implications of behavioural economics for financial literacy and public policy. The Journal of Socio-Economics, 41 77-690. http://dx.doi.org/10.1016/j.socec.2012.06.002

American Institute of Certified Public Accountants, 2008. Financial literacy: Knowing what you need to know to achieve your financial goals. Available http://www.in.gov/gpcpd/files/Financial_Literacy__Large_Print.pdf, Retrieved 17.09.2013

Andreasen, A. R. (2002). Marketing social marketing in the social change marketplace. Journal of Public Policy and Marketing, 21 (1), 3-13. http://dx.doi.org/10.1509/jppm.21.1.3.17602

Atkinson, A., \& Messy, F. (2012). Measuring Financial Literacy: Results of the OECD / International Network on Financial Education (INFE) Pilot Study, OECD Working Papers on Finance, Insurance and Private Pensions, No. 15, OECD Publishing. http://dx.doi.org/10.1787/5k9csfs90fr4-en

Cole, S., Sampson, T., \& Zia, B. (2011). Prices or knowledge? What drives demand for financial services in emerging markets? Journal of Finance, 66 (6), 1933-1967. http://dx.doi.org/10.1111/j.15406261.2011.01696.x

Collins, J. M. (2013). The impacts of mandatory financial education: Evidence from a randomized field study. Journal of Economic Behavior \& Organization, 95 http://dx.doi.org/10.1016/j.jebo.2012.08.011

Dolnicar, S., Laesser, C., \& Matus, K. (2009). Online Versus Paper: Format Effects in Tourism Surveys. Journal of Travel Research, 47, 295316. http://dx.doi.org/10.1177/0047287508326506
Greenlaw, C., \& Brown-Welty, S. (2009). A Comparison of Web-Based and Paper- Based Survey Methods: Testing Assumptions of Survey Mode and Response Cost. Evaluation Review, 33, 464-480. http://dx.doi.org/10.1177/0193841X09340214

Ijevleva, K. (2014). Latvian Consumers' Financial Literacy in Home Loan Market in Marketing Context. University of Latvia, Doctoral Thesis, $251 \mathrm{p}$.

Klínský, P., \& Chromá, D. (2009). Finanční gramotnost-úlohy a metodika. Praha, Czechia: Národní ústav odborného vzdělávání. Národní strategie finančního vzdělávání

Kotler, P., Keller, K. L. (2011), Marketing Management, (14 ${ }^{\text {th }}$ ed.). Prentice Hall, 816 p.

Kotler, P., \& Zaltman, G. (1971). Social marketing: An approach to planned social change. Journal of Marketing, 35 (3), 3-12. http://dx.doi.org/10.2307/1249783

Latvian population's financial literacy strategy 2014-2020 Available http://www.fktk.lv/texts_files/0_Strategijas_makets_final.pdf Retrieved 24.02.2014.

Lo Prete A. (2013). Economic literacy, inequality, and financial development. Economics Letters, 118, 74-76. http://dx.doi.org/10.1016/j.econlet.2012.09.029

Meiera, S., \& Sprenger, D. C. (2012). Discounting financial literacy: Time preferences and participation in financial education programs. Journal of Economic Behavior \& Organization, 73, 50-57.

Morris, Z. S., \& Clarkson, P. J. (2009). Does social marketing provide a framework for changing healthcare practice? Health Policy, 91 (2), 135-141. http://dx.doi.org/10.1016/j.healthpol.2008.11.009

OECD (2009). The OECD project on financial education. OECD Publishing.

Praude, V., \& Šalkovska, J. (2005-2006). Mārketinga komunikācijas. Rīga: Vaidelote, $488 \mathrm{p}$

Robertson, K., \& Davidson, J. (2013). Gender-role stereotypes in integrated social marketing communication: Influence on attitudes towards the ad. Australasian Marketing Journal, 21, 168-175. http://dx.doi.org/10.1016/j.ausmj.2013.05.001

Schonlau, M., Asch, B., \& Du, C. (2003). Web Surveys as Part of a MixedMode Strategy for Populations That Cannot Be Contacted by E-mail. Social Science Computer Review, 21, 218-222. http://dx.doi.org/10.1177/0894439303021002007

SEDI, Environmental Scan of Financial Capability Products and Services in Canada, (Toronto: SEDI, 2006)

Van Rooij, M.C.J., Lusardi, A., \& Alessie Rob, J.M. (2011). Financial literacy and retirement planning in the Netherlands. Journal of Economic Psychology, 32 http://dx.doi.org/10.1016/j.joep.2011.02.004

Worthington, A. C. (2006). Predicting financial literacy in Australia, Faculty of Commerce, University of Wollongong, Wollongong.

Sergejs Paramonovs graduated from the University of Latvia in 2014. He wrote his Master thesis on airport efficiency influencing factors. His knowledge and experience has extended by years of studies and applied work in the field of clinical psychology. Whilst having decided to practice psychotherapy and psychology as a hobby, he is pursuing his further academic and goals in business. Whilst working in top management positions in the USA (Chicago) and Europe (Latvia) he has proven to be an effective crisis manger and is known for introducing new effective ways of organization in management and operations.

Presently, he is developing business for SPLAT Cosmetics and is a part of a team bringing the company into the global market. His recent achievements are bringing the company into eight countries in Europe for a twelve month period and reaching a contract with one of the largest European retailers, El Corte Ingles (Spain).

E-mail: sergeypar@yahoo.com

Ksenija Ijevleva received the Dr. oec. degree from the University of Latvia in 2014. She completed her master studies in management with honours (Summa Cum Laude) in 2010. During her studies she concentrated on such topics as banking and consumers' financial literacy. She has taken part in the international project URBACTII, where she conducted research on social mood (2010-2012).

She worked as analyst and project manager at DNB banka for 6 years and as financial analyst at BIGBANK for 1 year. Her present scientific interest is related to analysis of consumers within universal banking area.

E-mail: kijevleva@inbox.lv 